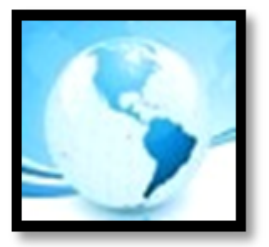

July 2018, VOLUME 6, ISSUE 3, 1 - 28

E-ISSN NO: $2289-4489$

https://doi.org/10.22452/mojem.vol6no3.1

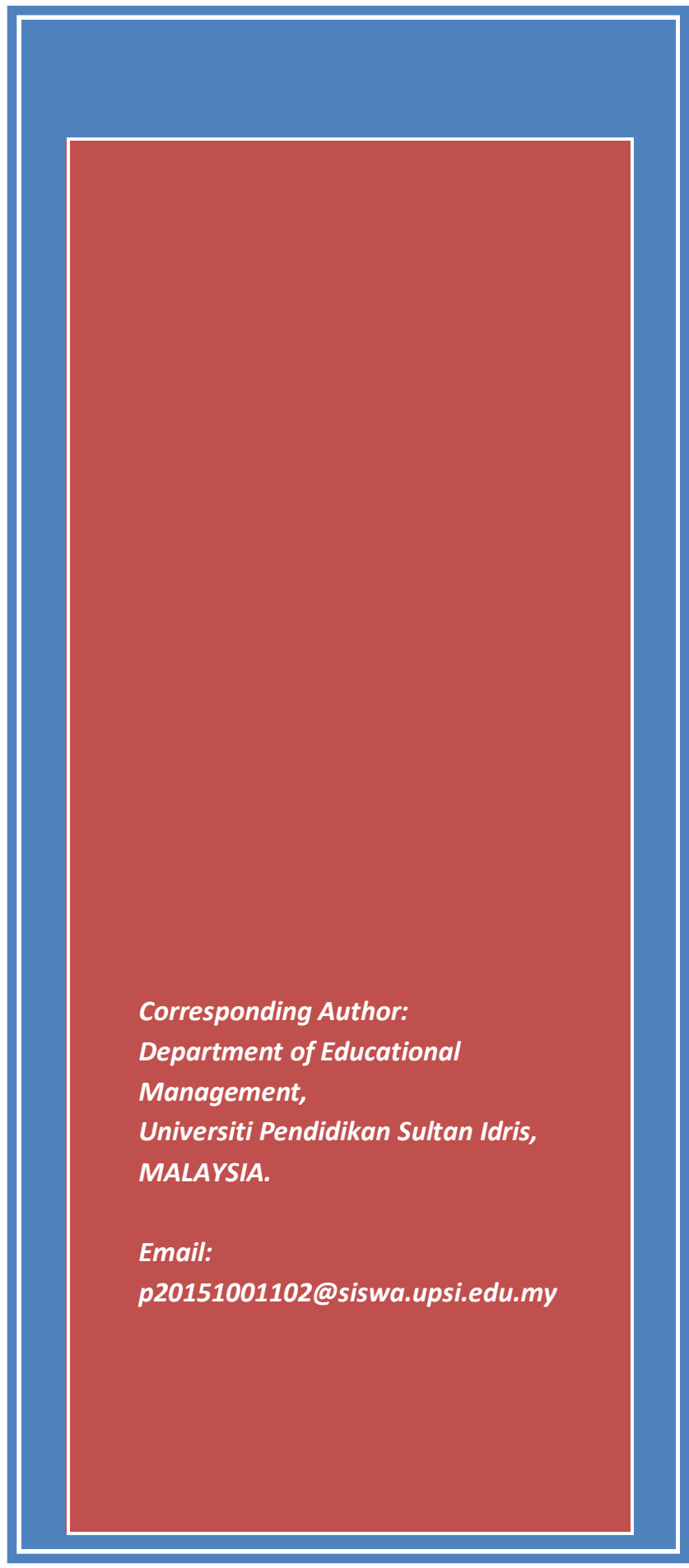

\section{DEVELOPING AND VALIDATING MODEL OF TEACHER QUALITY USING STRUCTURAL EQUATION MODELING (SEM) TECHNIQUE}

Saleman Mashood Warrah, Khuan Wai Bing (PhD) \& Hamidah Binti Yusof (PhD)

\begin{abstract}
The main objective of this study is to establish Teacher Quality model (TQM). The study also aimed to identify the relationships between teacher quality (TQ) and students' academic performance (SAP). Furthermore, the study also seeks to verify the relationships among TQ dimensions. Structural Equation Modeling was used to test the model. A total of 450 teachers from secondary schools in Kwara state, Nigeria completed the survey. The analysis yielded four dimensions for Teacher Quality, namely Teacher Knowledge; Communication Skills; Teacher Commitment and Classroom Management for the improvement of the students' academic performance. The findings show that TQ model will be of benefits to teachers in schools on how these skills can be used to improve students' academic performance. The result of the study also reveals that TQ dimensions were significant at increasing SAP. As the findings confirmed that the Teacher Quality (TQ) matters in determining students' academic performance (SAP) it is a sine qua non (condition) for school teachers to abreast themselves with the requisite qualities the teaching requires to improve students' academic performance which in turn increase the quality of education. The fits for the model were significant at $>0.9$. Also, TQ has a role to play in the school system for the realization of educational objectives. The findings encourage the school principal to establish development programme that will impacted positively on teachers' development for the benefits of the students so that their academic performance would be achievable.
\end{abstract}

Keywords: Teacher Quality, Teacher Knowledge, Communication Skills, Teacher Commitment, Classroom Management. 


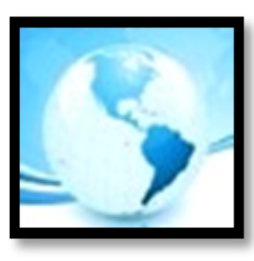

\section{MALAYSIAN ONLINE JOURNAL OF EDUCATIONAL MANAGEMENT (MOJEM)}

\section{INTRODUCTION}

Education is as old as human beings and there is no nation without any form of education. Education given to anybody is essential to the pace of economic, political and social development of any nation (Olujuwon, 2002). The World Conference on Education in Jomtien on 2006 is even entitled "Education for all" which meant that education is an inalienable right for everybody, men and women of all ages all over the countries. That is why the majority of countries make every effort to allocate huge amount of money for its education. For any nation to attain these national aspiration, secondary schools are expected to provide quality instructions that will be oriented towards instilling value for the worth and dignity of a person; capability to make judicious decision, share responsibility for the society, moral and spiritual values in interpersonal relationship among other (Etuk, Afangideh, \& Uya, 2013).

The Federal government of Nigeria described secondary education as an intermediary stage of education. These stages determine what students will then pursue to study in tertiary institutions. Due to that, classes are divided into commercial class, science class and art class. Nigeria operates a 6-3-3-4 system of education, six years in primary, three years in junior school, three years in senior school and four years in tertiary institution (Aluede, 2009). Generally speaking, the quality of educational system depends on the quality of teachers employed who possess academic qualifications and experience (Ameen, 2012; Arinde, 2010). In Nigeria for example, there were 10, 000, 6403 teachers and of which 4, 000, 5007 are secondary schools teachers with teaching qualification such as B.Ed. and M.Ed (Federal Ministry of Education, 2016). Arinde (2010) and Ige (2017) affirmed that quality and effective learning depends solely on retention, recruitment, and selection of teachers needed to increase the level of performance and the quality of education.

The students' academic performance has been declining for four consecutive years which became a debatable issue in the country. The results in the students' final examination before going to higher institution was not encouraging (Yaro Ibrahim, Arshad, \& Salleh, 2017). These students then cannot be admitted into universities and they have turn to menace in the society. Due to that, the parents and stakeholders in education pointed their accusing finger on the government as well as on the teachers for the failure of the students. For that reason, there is need to investigate the cause of students' poor academic performance. The Table 1 shows declining in the students' examination from 2014 to 2016.

Table 1

Percentage difference in yearly examinations

\begin{tabular}{lll}
\hline Years & Percentages & Difference \\
\hline 2014 & 38.81 & - \\
2015 & 36.57 & 2.24 \\
2016 & 31.28 & 5.29 \\
\hline
\end{tabular}

However, this research aimed to answer the question of: Can teacher quality be explained by dimensions of teacher knowledge, communication skill, teacher commitment and classroom management?

\section{Conceptualizing Teacher Quality (TQ)}

Teacher quality is the process whereby teachers engage in educational functions, with particular qualities and being qualified to conduct teaching activities, arousing students' interest in learning, and improving students' academic performance (Wenglinsky, 2001, Lin, Xie, Jeng, \& Huang, 2010). Teacher quality is a broad term for teacher cultivation, abilities and qualification. 


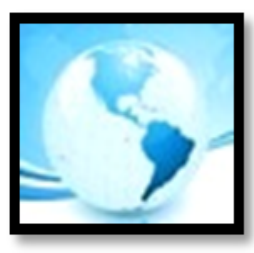

Accordingly, the content of teacher quality can be grouped into: 1) professional knowledge and abilities, 2) professional subject accomplishment, 3) common quality, 4) professional beliefs and attitude 5) personality. In another way, Wu (2013) further divided teacher quality into three stages: 1) morals, 2) knowledge and 3) abilities.

In sum, Wang and Fwu (2007) stressed that teacher quality is important for the teaching activity with students and is the only key for effective teaching. Addressing this point, Hanushek and Rivkin (2006) revealed that it is reasonable to seek for quality in education because teacher quality help teachers discover their shortcoming in order for them to not only improve themselves but also increase their teaching efficiency. In turn, teachers with good effectiveness usually value their teaching performance and sustain their teaching quality while pursuing the best teaching effectiveness. Therefore, this would increase students' academic performance (Lin et al., 2010).

\section{Model of Teacher Quality developed by Goe (2007)}

In line with Goe model on teacher quality, there are differences between teacher quality and teaching quality because of the dilemma that occurred in the process of definition of teacher quality. Teacher quality means a set of inputs like (college degrees, teachers' test scores and certification) that signify who will perform well in a class situation. In contrast, teaching quality refers to what the teachers offer in the class which determines their quality. Therefore, it is assumed that teacher quality brings teaching quality or teaching quality is the result of teacher quality. It is interesting know more about the other scholarships of teacher quality, which includes works from researchers (e.g. Ololube, 2005; Hanushek \& Rivkin, 2006; Lin et al., 2010; Wang \& Fwu, 2007) who have contributed immensely to the development of teacher quality.

In the given Table 2 are the synthesized literatures investigated on teacher quality. Figure 1 also depicted the model of teacher quality with elements which are grouped into three dimensions namely; input, process and outcomes. 


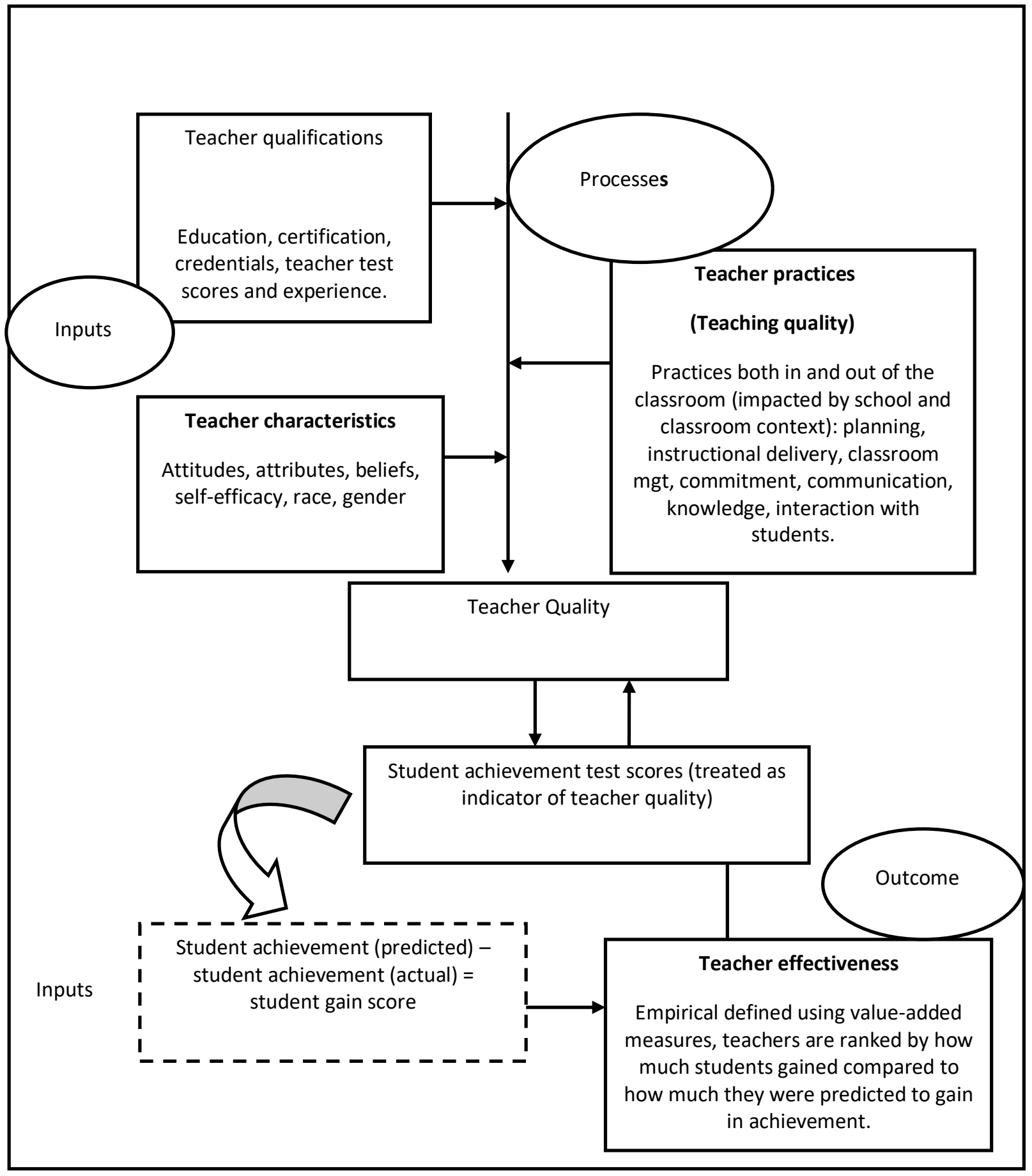

Figure 1. Model for Teacher Quality (source: Goe, 2007) 


\section{The Contribution of Goe's (2007) Model on Teacher Quality}

a. One of the contributions of Goe's (2007) model to teacher quality is that teachers must have requisite qualifications (inputs) before they can fit into a teaching profession. The qualifications mentioned by Goe (2007) are certification, credentials, teacher test scores as well as experience. They serve as major determinant for both teaching quality and to improve students' academic performance.

b. Hence, the model developed by Goe (2007) simply emphasized that there should be unique qualities which teachers must employ into teaching profession. The teacher qualities mentioned are the self-efficacy, beliefs, attitudes, and status. These qualities have colossal impact on the performance of students in the classroom situation.

c. In addition, contribution of the model stressed that teacher quality can be used to facilitate effective teaching in the school. Furthermore, it should be noted that in order to facilitate effective teaching, not only inputs are needed, but the process that will make it possible are; the planning, instructional delivery, classroom management, commitment, communication, knowledge and interaction with the students.

d. Lastly, the model proved that students' performance solely relies on quality of input and the quality of process given to education. 
Table 2

Comparison of Literature on Teacher Quality

\begin{tabular}{|c|c|c|c|c|c|c|c|c|c|c|c|c|c|c|}
\hline \multirow[t]{2}{*}{ Characteristics } & \multicolumn{14}{|c|}{ Authors Description } \\
\hline & $\begin{array}{l}\text { Coh } \\
\text { en, } \\
199 \\
8\end{array}$ & $\begin{array}{l}\text { Bell, } \\
(200 \\
2)\end{array}$ & $\begin{array}{l}\text { We } \\
\text { ngli } \\
\text { nsk } \\
\text { y, } \\
200 \\
1\end{array}$ & $\begin{array}{l}\text { Rice, } \\
2003\end{array}$ & $\begin{array}{l}\text { God } \\
\text { dar } \\
\text { d, } \\
\text { Hoy } \\
\text { \& } \\
\text { Hoy } \\
\text { ' } \\
200 \\
0\end{array}$ & $\begin{array}{l}\text { Cavalluz } \\
\text { zo, } \\
2004\end{array}$ & $\begin{array}{l}\text { Gold } \\
\text { habe } \\
\text { r \& } \\
\text { Anth } \\
\text { ony, } \\
2005\end{array}$ & $\begin{array}{l}\text { Carr, } \\
2006\end{array}$ & $\begin{array}{l}\text { Harri } \\
\text { s \& } \\
\text { Sass, } \\
2007\end{array}$ & $\begin{array}{l}\text { Mey } \\
\text { er\& } \\
\text { Malt } \\
\text { in,20 } \\
10\end{array}$ & $\begin{array}{l}\text { Arin } \\
\text { de, } \\
2010\end{array}$ & $\begin{array}{l}\text { Kim } \\
\text { Kim } \\
\text { Lee, } \\
\text { Lee, } \\
\text { Spe } \\
\text { ctor } \\
\text {, \& } \\
\text { De } \\
\text { Me } \\
\text { est } \\
\text { er, } \\
201 \\
3\end{array}$ & $\begin{array}{l}\text { Lus } \\
\text { ko } \\
\text { va } \\
\& H \\
\text { ud } \\
\text { ak } \\
\text { ov } \\
\text { a, } \\
20 \\
13\end{array}$ & $\begin{array}{l}\text { Palo } \\
\text { S } \\
\text { \&Pet } \\
\text { rovic } \\
\text { i, } \\
2014\end{array}$ \\
\hline $\begin{array}{l}\text { 1.Teacher } \\
\text { qualifications }\end{array}$ & & & & & & & & & & & & & & \\
\hline -Training & & & & & & & & & $\bullet$ & & & & & \\
\hline -Certification & & & & & & $\bullet$ & & & & & & & & \\
\hline -Test scores & & & & & & & $\bullet$ & & & & & & & \\
\hline -Experience & $*$ & & & & & & & & & & & & & \\
\hline $\begin{array}{l}\text { 2. Teacher } \\
\text { characteristics }\end{array}$ & & & & & & & & - & & & & & & \\
\hline -Attitudes & & & & $\bullet$ & & & & & & & & & & \\
\hline -Beliefs & & & & & & & & & & & & 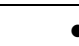 & & \\
\hline -Self efficacy & & & & & 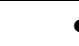 & & & & & & & & & \\
\hline $\begin{array}{l}\text { 3. Teacher } \\
\text { practices }\end{array}$ & & & & & & & & & & & & & & \\
\hline -Planning & & & & & & & & & & & & & & \\
\hline $\begin{array}{l}\text {-Instructional } \\
\text { delivery }\end{array}$ & & $\bullet$ & & & & & & & & & & & & \\
\hline $\begin{array}{l}\text {-Classroom } \\
\text { Management }\end{array}$ & & & & & & & & & & & & & & \\
\hline -Commitment & & & & & & & & & & $\bullet$ & & & & \\
\hline - & & & & & & & & & & & & & & $\bullet$ \\
\hline 4. Outcome & & & & & & & & & $\bullet$ & & & & & \\
\hline $\begin{array}{l}\text {-Teacher } \\
\text { performance }\end{array}$ & & & & & & & & & & & & & & \\
\hline $\begin{array}{l}\text {-Students' } \\
\text { performance }\end{array}$ & & & & & & & & & & & $\bullet$ & & & \\
\hline
\end{tabular}




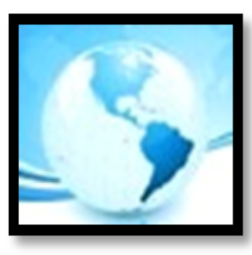

\section{CONCEPTUAL FRAMEWORK}

The conceptual framework of the study was developed in line with the underpinned theories which contain teacher performance (Elger, 2007); teacher knowledge (Shulman, 1986); teacher commitment (Meyer \& Allen, 1991); classroom management (Wolgang \& Glickman, 1980); communication skills (Vygotsky, 1962) and teacher quality (Goe, 2007) which play vital roles in the development of the conceptual model.

\section{Teacher Knowledge}

For decades, educational manager and policy makers have been worried about what can bring efficiency to teaching and learning (Ahn \& Choi, 2004; Rubio, 2009). Teachers' subject matter knowledge has been noted to be a crucial determinant for students' academic performance. Ball and McDiarmid (1989) delineated that a good knowledge of teaching must be involved in giving helpful explanation, evaluating student learning, selecting worthwhile learning activities, asking productive questions. All of these are depending on the teachers' understanding of the students' abilities. Thus, in recognition of teacher knowledge skills, Adedoyin (2011) defined teacher knowledge of subject as the knowledge on how to transform formal subject knowledge into a meaningful outcome for learners and it involve deep knowledge of a particular topic and how teachers present it in simple manner to their students. Teachers are expected to display the skills they have acquired to students in the classroom setting. Moreno (2009) noted that good content knowledge is just one of the crucial factors and qualities needed by teachers in order to improve students' academic performance.

In light of that, Niess (2011) found that teachers need to show their skills while teaching in the classroom such as knowledge of subject matter, knowledge of learners' development, and organization of teaching methods. These skills will definitely improve both the teachers' students' performance in the classroom environment. According to NCTM (2000), teachers who possess strong subject matter knowledge often give detains in their lesson, link the topic to other topics, and demand many questions from students. Furthermore, Shulman (1986) classified teachers' knowledge into different components known as Pedagogical Content Knowledge (PCK) model. Shulman (1986) opined that PCK is the knowledge the teachers use in transforming content knowledge to form what is understandable to the learners. Subject matter knowledge covers series of actions from the representation of ideals in various forms, instruction selection of teaching methods to adapting, tailoring specific learners and context and preparation of materials.

\section{Communication Skills}

Communication skill is one of the vital elements of effective teaching and learning to increase students' academic performance (Moreno, 2009). Teachers are required to possess good communication skills that will make their teaching more understandable (Das, 2014). In a school, teachers need to understand the concept that they want to deliver to their students. In another development, a research by Moll, Cathy, Neff and Gonzale (1992) opined that the role of the teacher is not just to lead or establish structural sign, but to help learner through exploratory talk and other social mediation like bringing different activities into classroom or allowing them to take control of their own learning. The ability of the efficient teacher becomes significant to the construction of knowledge and ideas of the learner. Some of the communication skills the teachers must explore during classroom interaction are as follows: 


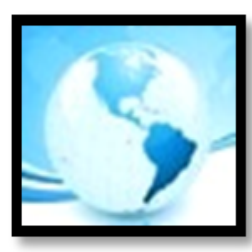

\section{MALAYSIAN ONLINE JOURNAL OF EDUCATIONAL MANAGEMENT (MOJEM)}

- Body Language- this is a great communication skill that a teacher must have. Correct communication skills include powerful body language assisted by verbal mechanism. This would last in the mind of students and they would be able to attend that teacher class.

- Understanding the Students- teachers should always motivate the students to exchange a few words overtly.

- Group Formation- this is an important method for teachers to divide the students into groups and give them problems to solve. This would assist teaching and learning, and interaction between teacher and students can also increase.

- Encouraging Motivation- this is another area of interest for teachers to develop whilst teaching in the class. There are individual differences among the students; wherein some may like the subject while some may dislike it. Therefore, it is a normal duty for the teachers to create an avenue for such students to participate in the discussion. The teacher's duty is to free the students from any anxiety and fear in classroom learning.

- Asking Effective Questions- teacher can use his/her teaching techniques to ask questions about what students have learnt. This would improve the introvert students and effectiveness of teaching would take place.

\section{Teacher Commitment}

Teaching requires dedication, commitment and excitement. Teacher remains a vital instrument in any educational system by playing an important role in promoting education by improving the abilities of students through the nature of their work (Mart, 2013). However, commitment developed by teacher to teaching will further improve the performance of students. Abdul Rasaq, Norhasni, Zalizan, and Anisa (2010) stressed that teacher commitment has been used for teacher quality and a committed teacher has been used interchangeably for dedicated teachers. By considering the view of Mart (2013) that the teacher commitment is a strong emotional bond that the educational workers have towards the schools. Commitment is a job attitude that drives the individuals to be willing to work harder to accomplish objectives (Vasudevan, 2013). Teachers who love to teaching would exhibits a hardworking attitude and derived satisfaction from it.

In fact, teachers who are committed to work will be after students' progress, caters for them and guide them to accomplish the learning outcome (Elliott \& Crosswell, 2001, Aurier \& Lanauze, 2012). A committed teacher would wait until closing time to see students leaving the school and take teaching as their life styles or a calling. Teachers in this category can organize excursion programs for students for the purpose of discovering and exploring some of the real things they have discussed in the class (Choi and Tang, 2009). Meyer and Allen (1991) proposed a threecomponent model of organizational commitment (TCM) for employees committed to a place of work.

Meyer and Allen (1991) propounded three models of commitment have been measuring employees' organizational commitment. Affective Commitment ( $A C$ ) is employees' emotional attachment and involvement in the organization. Employee who is committed to the organization or emotionally attached to the organization, believe in the values and goals of the organization, work for the success and stay permanently with the organization. Continuance Commitment (CC) is the employees' awareness of perceived cost of leaving the organization. This is the readiness of the employee to remain in the organization because of the investment that employee had with organization. Meyer and Allen (1991) noted that investment organization as any actions that would result in loss in organization determine commitment. This could be performance bonus, sick leave, friend relationship and car loan. 


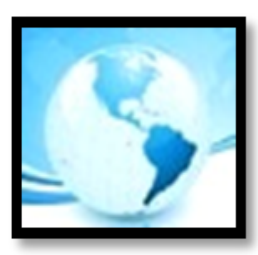

\section{MALAYSIAN ONLINE JOURNAL OF EDUCATIONAL MANAGEMENT (MOJEM)}

Before employees could think of leaving, he/she would think twice. Normative Commitment (NC) is the employees feeling of obligation to remain permanently with the organization. Normative could also mean psychological contract between an employee and the organization (Meyer \& Allen, 1991). Religion and employment, family, commitment to marriage and loyalty and devotion are things employees consider before leaving the organization.

\section{Classroom Management}

Classroom management skill is one of the qualities teachers must possess in order to improve students' performance (Rubio, 2009). Classroom management control is one of the serious problems faced by teachers of today and it is the heart of teaching and learning (Adeyemo, 2012). The classroom environment should be well controlled to the extent of creating conducive learning, and relatively free from nuisance and bad behaviour in the class. It is the ineffectiveness of classroom techniques that causes indiscipline among the students which hinder effective learning (Osakwe, 2014).

Further, classroom management skills encompass time management, controlling students behaviour (Chamundeswari, 2013), managing both introvert and extrovert students, sitting arrangement among others (Ameen, 2012). Indeed, classroom management skills centre on the teacher attitude, desires, setting of expectations and quality environment. To have a safe classroom behaviour and students' social skills, teachers must understand the teaching process and classroom management principles for making decisions on class organization (Osakwe, 2014). Venkat (2010) asserted that a good and well managed classroom is equal to consistent discipline and rewards. Besides, Osakwe, (2014) and Jones, Watson, Gardner and Gallois (2004) enumerated skills for teachers while teaching in the classroom. The enumerated skills are:

- The use of incentives to encourage students and even for counselling service for the nuisance one.

- To create love, affection and trusts and listen to students' suggestion, ideas and complaints.

- To treat them equally without favours.

- To make simple rules and regulations that is easily understand by the students.

- Arrange sitting space that allows free movement of people

- To use instructional methods that could bring good learning 

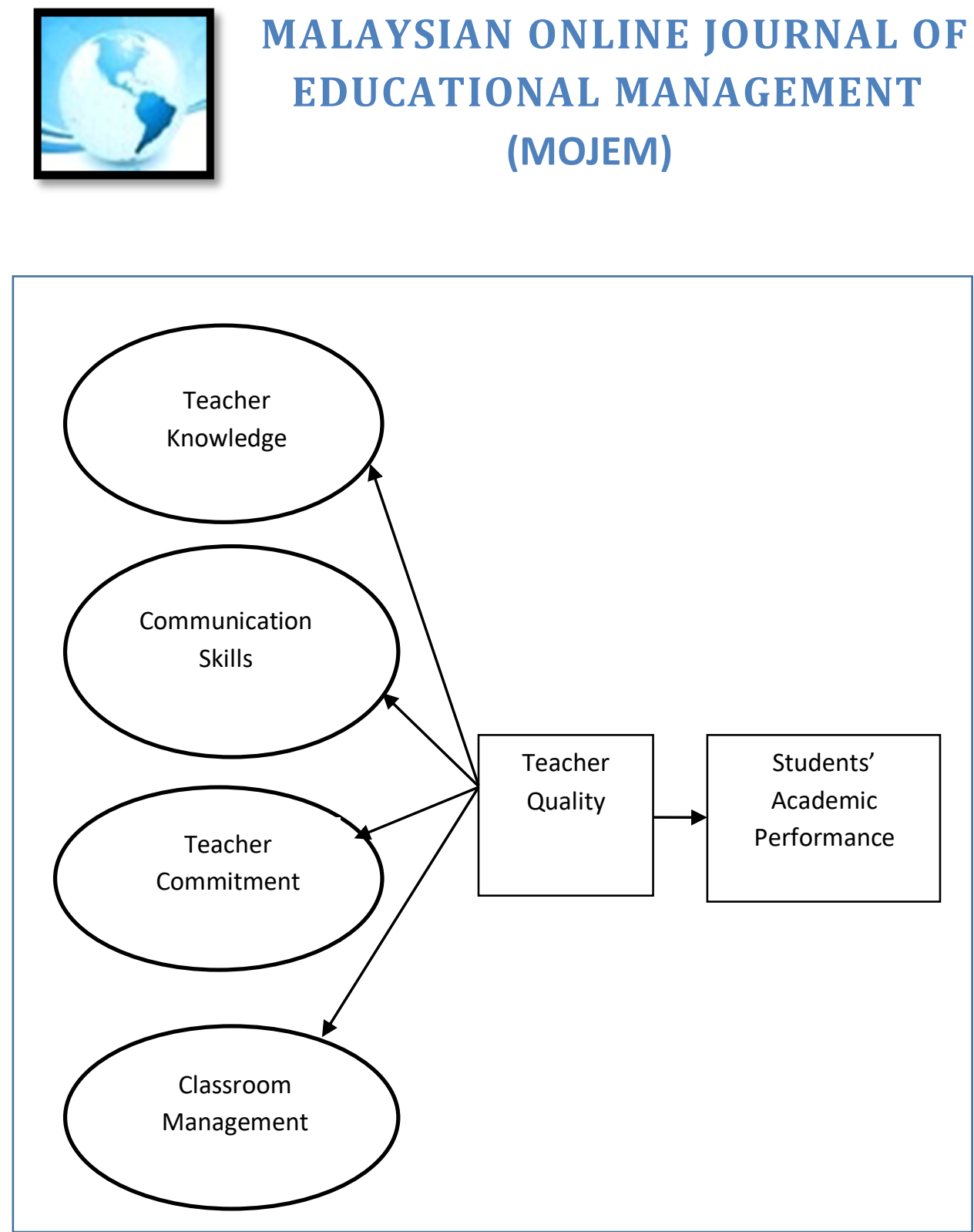

Figure 2. The model of Teacher Quality

\section{Research Question and Hypotheses}

Based on the research objectives and conceptual model to guide the study. The hypotheses were as follows:

$\mathrm{H}$ : There is significant relationship among dimensions of teacher quality.

$\mathrm{H}_{1}$ : Teacher quality has effect on teachers' knowledge.

$\mathrm{H}_{2}$ : Teacher quality has effect on teachers' communication skills.

$\mathrm{H}_{3}$ : Teacher quality has effect on teachers' commitment.

$\mathrm{H}_{4}$ : Teacher quality has effect on classroom management. 


\section{METHODOLOGY}

\section{Population and Sampling}

The study population for this research consisted of 450 public secondary school teachers in Nigeria. The teachers were chosen because they were possessing the quality which to improve the students' academic performance. The data collected from them was momentous for this study and the researcher identified which qualities lead to students' academic performance. Stratified sampling technique was used in this study because of suitability for the study was crucial (Daramola, 2006). There were sixteen stratums or local governments exist in Kwara state namely Asa (32), Baruten (21), Edu (24), Ekiti (11), Ifelodun (42), Ilorin East (27), Ilorin South (47), Ilorin West (45), Irepodun (37), Isin (12), Kaiama (8), Moro (15), Offa (25), Oke-ero (9), Oyun (12) and Patigi (12). About 651 schools exist in the Kwara state which cut across the 16-stratum mentioned above. In this case, not all 651 schools that exist in the state was be used for the survey. The researcher had to select those schools that will participate in the research exercise through the process of proportionate stratified sampling. To achieve this method, the target sample size $(n)$ was divided by the total target population $(N)$. Thus, the proportionate of each quota was $1.28 \%$ (379/29420x100). This will give each school in the local government the equal opportunity to participate in the survey. Therefore, total sample for the study was 450 teachers which adequate for using structural equation modelling (Hair, Black, Babin, \& Anderson, 2010; Kline, 2005; Byrne, 2013).

\section{Instrumentation}

To develop a research instrument for the study, the researcher needed to adapt some questionnaires from eminent scholar in the field of teacher quality (Adedoyin, 2011; Hacicaferoglu, 2014; Ihmeideh et al., 2010; Smith, 2009; James, 2013; Solomon, 2007; Sowell, 2013 and Morgan, et al., 2010). In this study, teacher knowledge; communication skills; teacher commitment and classroom management are referred to as teacher quality (TQ). Therefore, the total number of items used for all the constructs of teacher quality is 22 .

Table 3

Instruments developed for Teacher Quality

\begin{tabular}{|c|c|c|c|}
\hline Latent Variables & Scales Adapted & Operationalization & \\
\hline & & Sub-Constructs & items \\
\hline \multirow[t]{4}{*}{ Teacher Quality } & Adedoyin, (2011) & Teacher knowledge & 5 \\
\hline & $\begin{array}{l}\text { Hacicaferoglu, 2014; } \\
\text { Ihmeideh et al., } 2010\end{array}$ & Communication Skills & 5 \\
\hline & $\begin{array}{l}\text { Smith, 2009; James, 2013; } \\
\text { Solomon, 2007; Morgan, } \\
2010\end{array}$ & Teacher Commitment & 6 \\
\hline & Sowell, 2013; Morgan, 2010 & Classroom Management & 6 \\
\hline
\end{tabular}




\section{FINDINGS}

\section{Confirmatory Factor Analysis of the TQ}

Structural equation modelling (SEM) using AMOS software with maximum likelihood was explored to test the model for the study. Confirmatory factor analysis was also tested for first and second-order measurement model. The model was re-specified so that acceptable goodness-of-fit can be determined. Then, convergent validity, discriminant validity and construct reliability were checked for the model. There were about 470 questionnaires sent out but only 450 were returned which accounted for $98 \%$ of response rate. The questionnaires were based on four constructs measuring teacher quality i.e. teacher knowledge, communication skills, teacher commitment and classroom management.

\section{The Results of First-Order Measurement Model of TQ}

As indicated in Figure 2, the TLI (.862) and CFI (.881) fit indicators lower the recommended value of .90 which means poor fit. The root-mean square error of approximation (RMSEA=.081) surpassed acceptable values. The NFI was .848 suggesting a poor fit for the model. Thus, the model needs to re-estimate to meet better fit for the model. Therefore, the model need to be re-run again. 


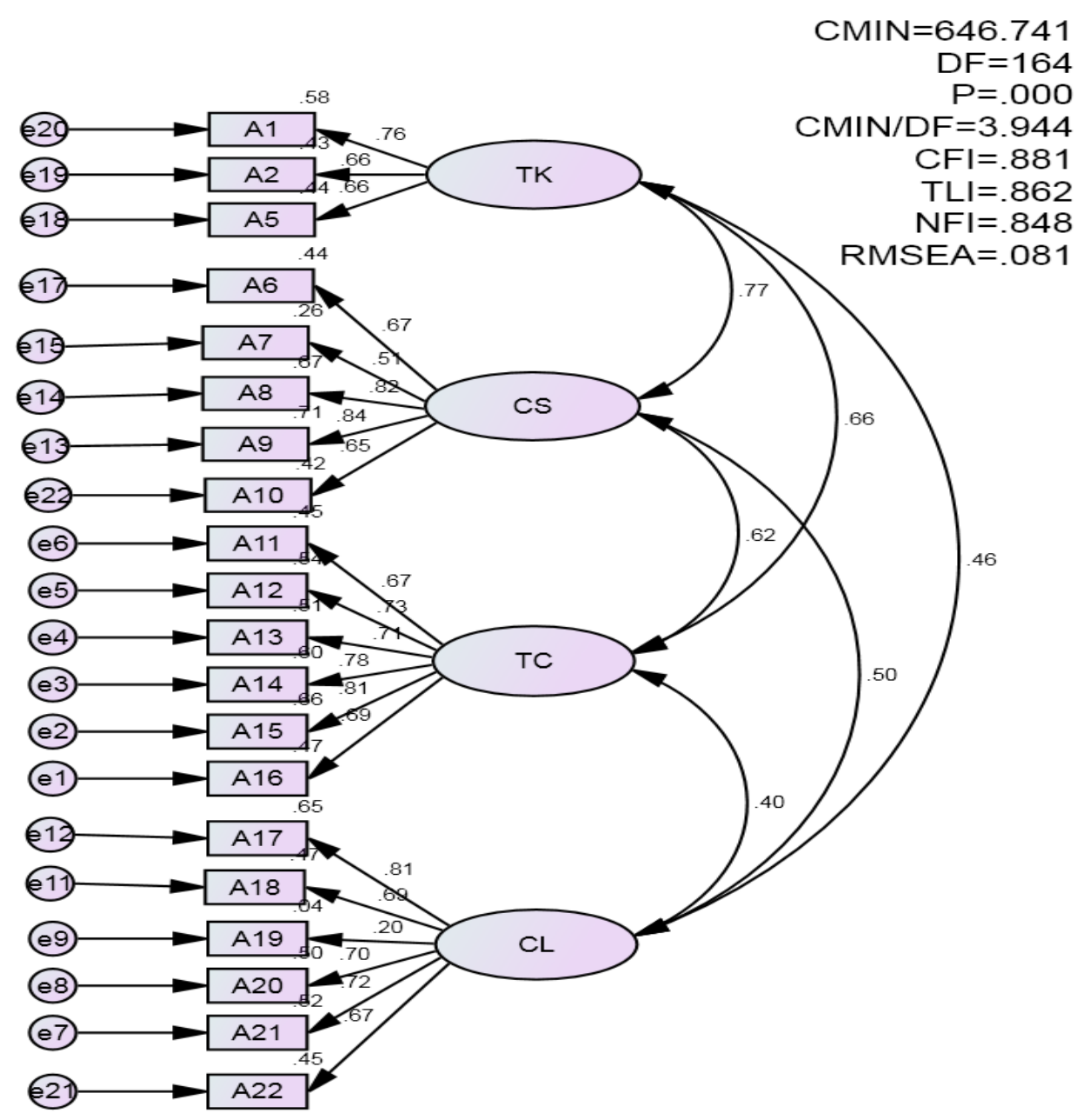

Figure 2. TQ First-Order Measurement Model

TK: Teacher Knowledge; CS: Communication Skills; TC: Teacher Commitment; CL: Classroom Management.

Next, the re-specification was applied again but the fits yet to improve due to small loading of some items. Items A7 and A19 were removed from the model. The fits were checked again but yet to improve and modification indices was also checked so that redundant items can be identify. 


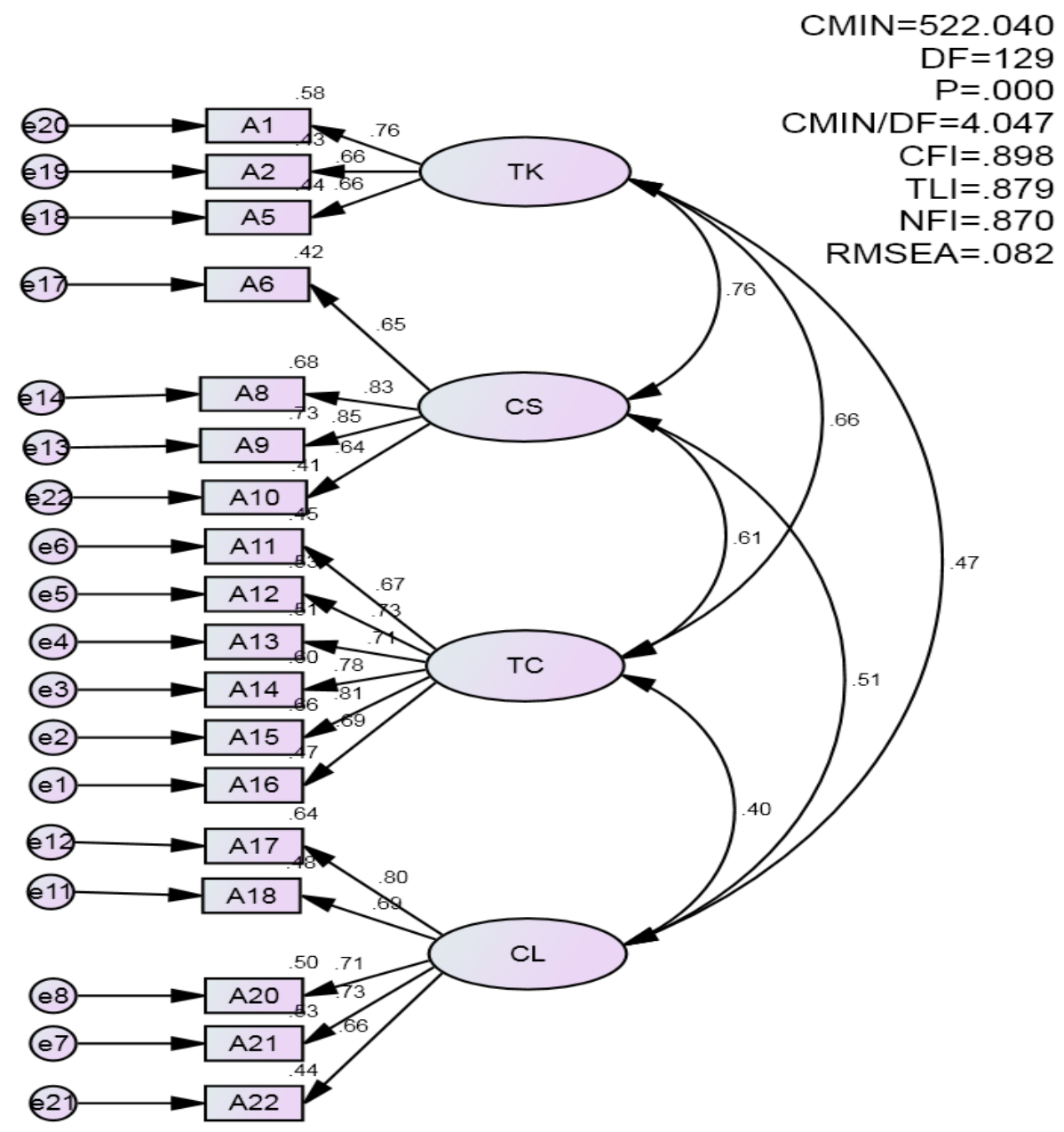

Figure 3. TQ First-Order Measurement Model 2

TK: Teacher Knowledge; CS: Communication Skills; TC: Teacher Commitment; CL: Classroom Management.

As shown in Figure 3, the modification indices suggested that item e6< $<$ e22 and e13<> e14 should be correlated as a free parameter in order for fits to be improve. Thereafter, when the model was run again, the fits improved simultaneously. In Figure 4, CFI was .936 which greater than the threshold of .90, indicating good fit. The TLI was also acceptable at .923 and NFI at .907 which means there were above the suggested value. The root-mean square error of approximation (RMSEA=.066) met the acceptable values. The Multicollinearity was not detected among the items loadings. The model was fit and suggesting further analysis to be performed. 


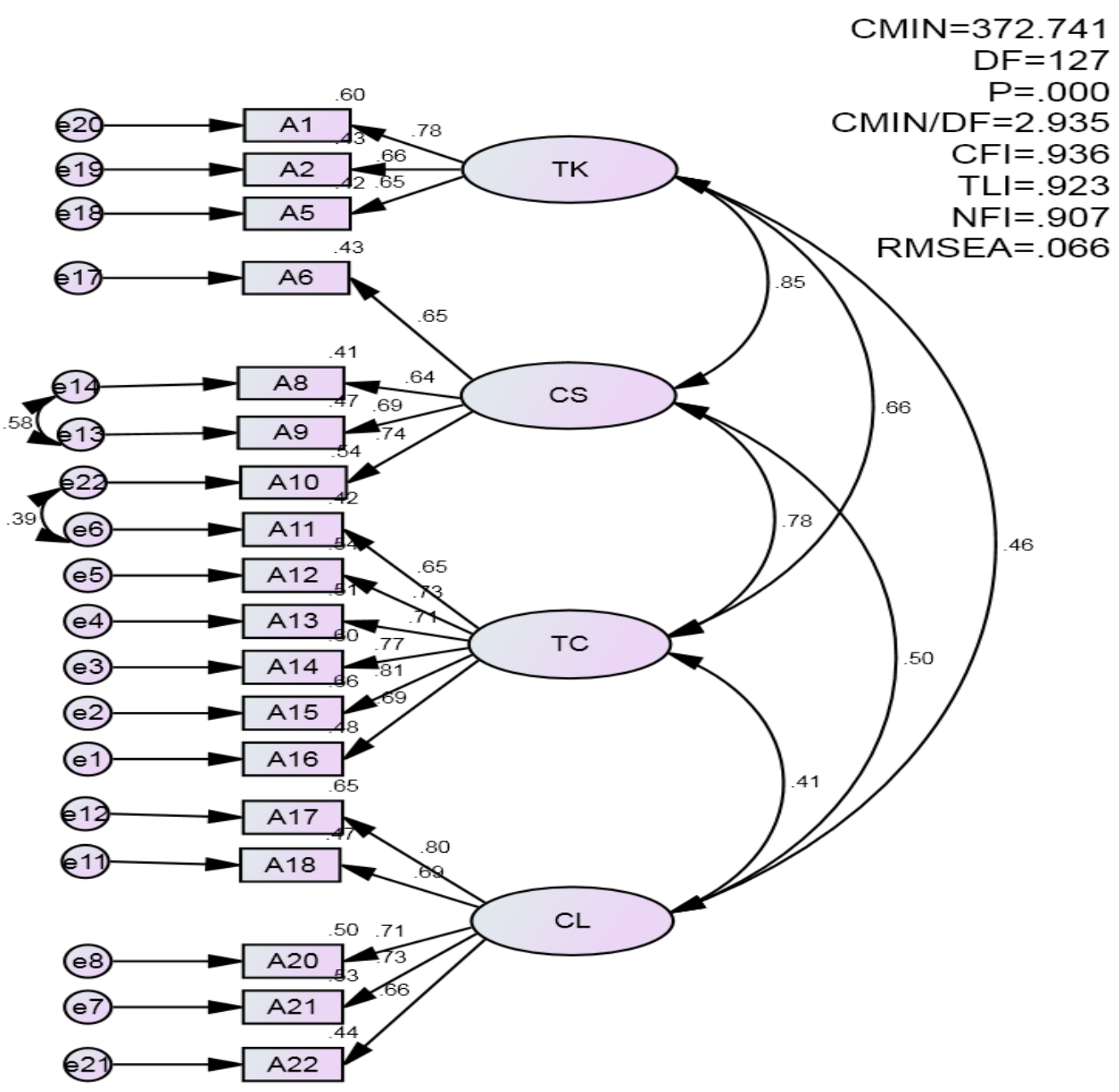

Figure 4. First-Orders CFA of TQ after the Redundant Items were constrained in the Model

\section{The Results of Second-Order Measurement Model of TQ}

The goodness fits in the first-order measurement model had been identified, and there was need to assess the model in second-order. According to the results revealed in Figure 5, the CFI indicating .931, TLI .920, NFI .900 and RMSEA .067. The goodness-of-fit for the model was statistically significant and they were above the all the set of thresholds. Teacher knowledge (TK) estimated .86, communication skills (CM) .96, teacher commitment (TC) .79 and classroom management (CL) .63. The results of four dimensions demonstrated a good factorial validity and indicating they can represented teacher quality. The four hypotheses for the study, $\mathrm{H}_{1}, \mathrm{H}_{2}, \mathrm{H}_{3}$ and $\mathrm{H}_{4}$ were supported. 


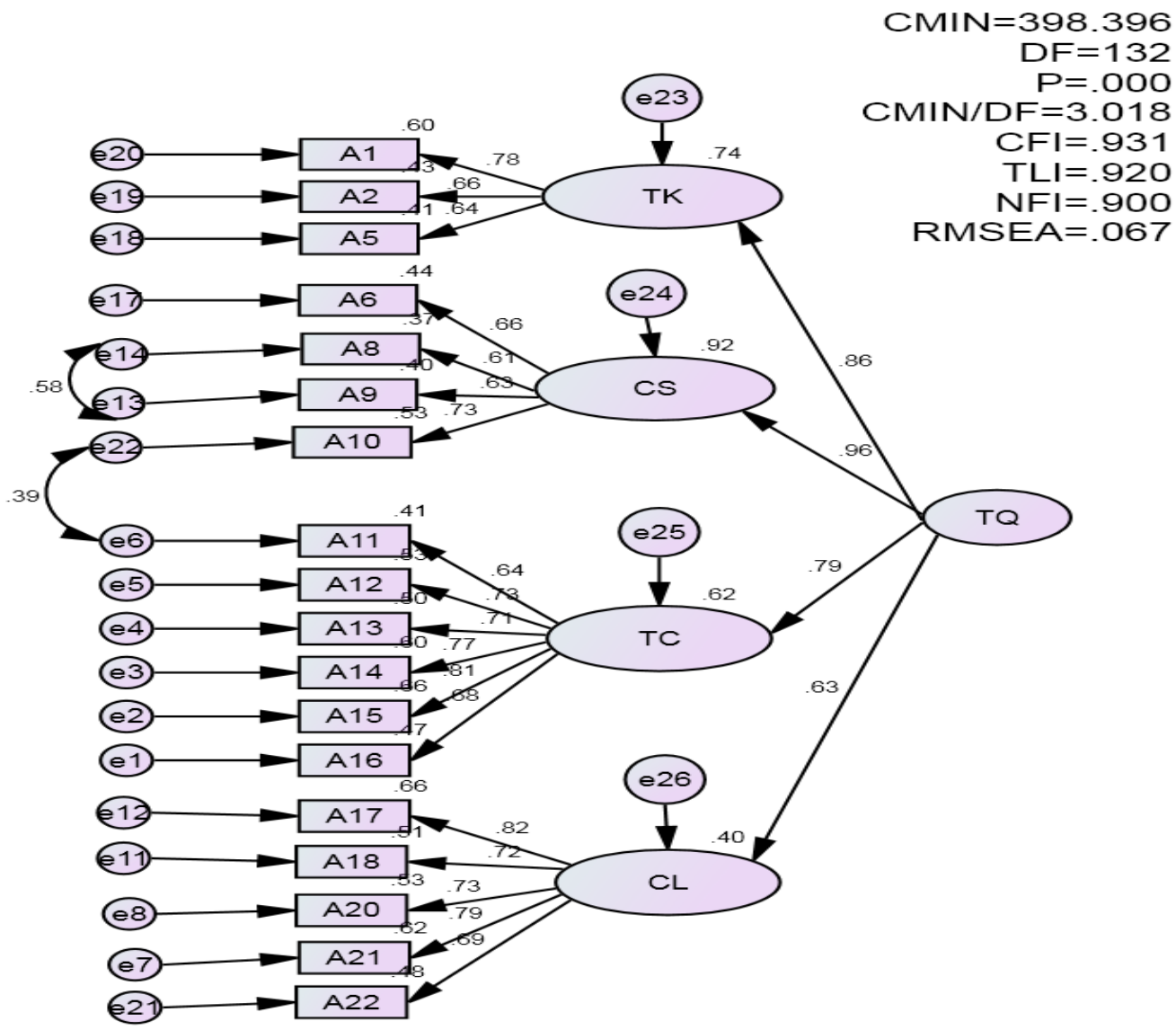

Figure 5. TQ Second-Order Measurement Model

TK: Teacher Knowledge; CS: Communication Skills; TC: Teacher Commitment; CL: Classroom Management; TQ: Teacher Quality.

\section{Convergent Validity}

As shown in Table 4, the results indicated that all loadings of TQ dimensions were significant at $(>0.50)$ stating from 0.60 to 0.80 . Then, the square multiple correlations (SMC) were greater than recommended value of 0.5 (Holmes-Smith, 2001; Vaus, 2002; Tabachnick \& Fidell, 2006; Hair et al., 2010, Sekaran \& Bougie, 2010). Next, average extracted values (AVE) above suggested values of 0.50 except TK and CS below 0.50 , composite reliability index (CRI) greater than 0.60 and Cronbach's alpha met the acceptable value at $>0.50$ (Fornell \& Larcker, 1981; Pallant, 2007; Rubin \& Babbie, 2007; Hair et al., 2010). These simplified that the TQ established a good evidence of convergent validity which means that items measure the sample taken from population of used for this study. 
Table 4

TQ standardized factor loadings, square multiple correlations, average variance extracted and composite reliability index

\begin{tabular}{|c|c|c|c|c|c|c|c|c|}
\hline & \multicolumn{2}{|c|}{ TK } & \multicolumn{2}{|c|}{ CS } & \multicolumn{2}{|r|}{ TC } & \multicolumn{2}{|c|}{$\mathrm{CL}$} \\
\hline & SFL & SMC & SFL & SMC & SFL & SMC & SFL & SMC \\
\hline TK1 & .78 & .60 & & & & & & \\
\hline TK2 & .66 & .43 & & & & & & \\
\hline TK3 & .64 & .41 & & & & & & \\
\hline CS6 & & & .66 & .43 & & & & \\
\hline $\mathrm{CS} 8$ & & & .61 & .37 & & & & \\
\hline CS9 & & & .63 & .39 & & & & \\
\hline CS10 & & & .73 & .53 & & & & \\
\hline TC11 & & & & & .64 & .40 & & \\
\hline TC12 & & & & & .73 & .53 & & \\
\hline $\mathrm{TC} 13$ & & & & & .71 & .50 & & \\
\hline TC14 & & & & & .77 & .59 & & \\
\hline TC15 & & & & & .81 & .65 & & \\
\hline TC16 & & & & & .68 & .46 & & \\
\hline CL17 & & & & & & & .82 & .66 \\
\hline CL18 & & & & & & & .72 & .51 \\
\hline CL20 & & & & & & & .73 & .53 \\
\hline CL21 & & & & & & & .79 & .61 \\
\hline $\mathrm{CL} 22$ & & & & & & & .69 & .47 \\
\hline AVE $(>0.50)$ & \multicolumn{2}{|c|}{$48 \%$} & \multicolumn{2}{|c|}{$0.43 \%$} & \multicolumn{2}{|r|}{$52 \%$} & \multicolumn{2}{|c|}{$56 \%$} \\
\hline CRI $(>0.60)$ & \multicolumn{2}{|c|}{0.69} & \multicolumn{2}{|c|}{0.65} & \multicolumn{2}{|r|}{0.72} & \multicolumn{2}{|c|}{0.75} \\
\hline $\begin{array}{l}\text { CRONBACH'S } \\
(>0.50)\end{array}$ & \multicolumn{2}{|c|}{0.728} & \multicolumn{2}{|c|}{0.819} & \multicolumn{2}{|r|}{0.874} & \multicolumn{2}{|c|}{0.752} \\
\hline
\end{tabular}

SFL: Standardized Factor Loadings, SMC: Square Multiple Correlations, AVE: Average Variance Extracted and CRI: Composite Reliability Index

\section{Discriminant Validity}

As shown in Table 5, the diagonal values that is in bolded font are the square root of AVE while values are the correlations between the respective dimensions or constructs. Thus, Discriminant validity for all dimensions for TQ were achieved because diagonal values (in bold) were greater than values in both the column and row.

Table 5

The Discriminant Validity Index Summary

\begin{tabular}{lllll}
\hline Constructs & TK & CS & TC & CL \\
\hline TK & $\mathbf{0 . 9 1}$ & & & \\
CS & 0.85 & $\mathbf{0 . 6 5}$ & & \\
TC & 0.78 & 0.78 & $\mathbf{0 . 7 2}$ & \\
CL & 0.46 & 0.50 & 0.41 & $\mathbf{0 . 7 4}$ \\
\hline
\end{tabular}






\section{Summary of Hypotheses Testing}

The results generated for teacher quality hypothesized model was accurate with data. Some of the items measured the underlying factors which mean that there was a significant relationship among the dimensions of teacher quality. In fact, the overall fit for the model was good with 19 items. The convergent, discriminant and construct reliability met the acceptable sets of thresholds. Therefore, all the hypotheses developed were answered in sequential. The summary of hypotheses and the results are shown in Table 6.

Table 6

Summary of Results of Hypotheses Testing for the Model

\begin{tabular}{llll}
\hline Hypotheses & Statement & Loadings & Results \\
\hline H1 & Teacher quality has effect on teacher knowledge. & .86 & Supported \\
H2 & Teacher quality has effect on teacher communication & .96 & Supported \\
& Skills. & & \\
H3 & Teacher quality has effect on teacher commitment. & .79 & Supported \\
H4 & Teacher quality has effect on classroom management. & .63 & Supported \\
\hline
\end{tabular}

\section{DISCUSSION}

There are four dimensions that measured teacher quality; teacher knowledge, teacher communication, teacher commitment and classroom management. These dimensions constitute teacher quality and how it could be used to enhance students' academic performance in secondary school. Teacher quality has 22 items which were developed and validated to determine the relationships among the constructs of teacher quality.

The first dimension of teacher quality is teacher knowledge in this present study. The result of the findings revealed that teacher knowledge was significant to determine teacher quality. Teacher knowledge skills must be possessed by teachers especially in area of subject matter. The result of this finding seems to be in line with Ahn and Choi (2004) which reveals that the good knowledge possessed by teachers can determine their effective teaching, good learning and quality of education. Accordingly, the result further indicates that knowledge is one of the top priority in which teachers in the teaching profession must strive to possess. Students excel greatly under teachers with quality knowledge of teaching than teachers without good knowledge of subject.

Nevertheless, the results appear to partially support the findings of Ball and McDiarmid (1989). In the study of Ball and McDiarmid (1989), it was revealed that knowledge of teacher based on subject matter can assist students in area of selecting worthwhile learning activities, asking productive questions, evaluating students learning, giving helpful explanation. In the same vein, the findings of Adedoyin (2011) also supported this result that knowledge of subject by the teacher is about transforming the students' life and building future confidence in them. Deep knowledge of teacher can make a teacher present his/her teaching into meaningful manner. Likewise, Moreno (2009) asserted that having a good knowledge of subject is one of the crucial qualities that enhance the quality work of teacher.

On top of this, teachers must seek for knowledge to increase the overall performance of students in secondary school. Niess (2011) pointed that teachers need knowledge skills in the classroom setting to orchestrate teaching methods, learners' development and learners' reliance as well. The result stated that in order to provide for quality education, teachers' knowledge of subject matter is a paramount factor to be put into consideration. Teachers who possess strong subject matter knowledge, who can give detain in the lesson, make the topic link to other topics and ask many questions from students is regarded as good teacher (NCTM, 2000). 


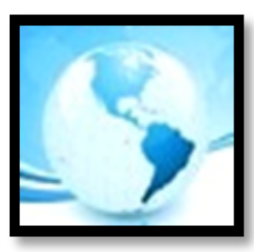

\section{MALAYSIAN ONLINE JOURNAL OF EDUCATIONAL MANAGEMENT (MOJEM)}

Shulman (1986) also corroborated that pedagogical content knowledge of teacher is a cardinal factor to determine the learners' success. For the purpose of understanding teacher knowledge, PCK model was developed by Shulman (1986) which explain the direct of teachers on the job. Wu (2013) asserted that PCK is very essential for effective teaching and increasing both teacher performance as well as students. PCK model include instruction selection of teaching methods to adapting, tailoring specific learners and context and preparation of materials.

Next, a teacher communication skill is found to be another factor of teachers' quality. Quality teachers facilitate students' academic performance and development. The finding suggested that effective communication skills determine how teachers will be able to teach students so that the subject could be understand by the students. Effective communication skills display by teacher leads to good performance of students. This result empirically supported by Palos \& Petrovici (2014) that communication behaviour like calling students by their names, smiling, using humour, praise, demanding polite question significantly improve teaching and learning. Prozesky (2000) expressed that good teachers can make a complex topic becomes simple for the students to understand better.

The finding was also congruent with Das (2014) that communication skills were paramount in the school setting in the presentation of lesson for students. Furthermore, teachers should try as much as possible to take communication skills as part of their skills so as to improve teaching. Teachers should see themselves as someone that can make a change in the system and be aware of the role their communication skills play in the life of learners. Researchers like Das (2014) and Chory and McCroskey (1999) believed that teachers are not born but instead, an ordinary person can be made successful through training, thus becoming a good teacher.

The findings were also supported by the research conducted by Das (2014); Moll et al. (1992) and Loy (2006) that the skills of asking effective questions, encouraging motivation, group formation, understanding the students' abilities can be internalized by the teacher. The ability of teacher become so vital to the construction of ideas to the learners understanding. Therefore, if teacher can communicate effectively to the students, quality teaching and quality learners will be produce and quality of education will take place.

Based on the above discussion, it is desirable for teachers in secondary schools to acquire good communication skills. Communication skills possess by teachers determining the success of the students in an examination. Das (2014) conform with result that effective communication lead to modification of behaviour of the students and teachers that make students learn present themselves accurately in the class. In fact, teachers can build communication skills by internalised reading culture on themselves and attending workshops regularly.

Apart from that, teacher commitment also found to be significant to determine teacher quality. Teaching job demanding dedication, tolerance and devotion. Commitment of teachers has been recognized as a tool that can led to effective teaching in the school. As Mart (2013) defined commitment as a strong emotional bond the teachers have towards the school. Commitment to job must be integrated by teacher to fostering students' academic performance.

The findings of this study were in line with Vasudevan (2013) and Mart (2013) that commitment is a job attitude that drives the individual to be willing to work harder to achieve objectives of an organization and stay in the job. The more the level of commitment, the greater the level of students' success and the performance of teachers. Joffress and Haughey (2001) was of opinion that teacher's commitment is a number one ingredient that make teacher to be effective in teaching. He further noted that teacher who likes to teach would exhibits hardworking and derived maximum satisfaction from it.

Various scholars like Elliott and Crosswell (2001); Day, Elliot and Kington (2005); Choi and Tang (2009) supported this finding that a committed teacher is one who is after students' progress, cater and guide to accomplish learning outcome. A committed teacher is one that waits till students close in the school. 


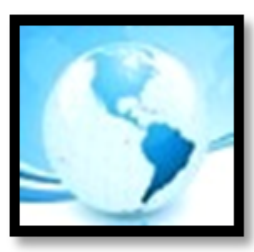

\section{MALAYSIAN ONLINE JOURNAL OF EDUCATIONAL MANAGEMENT (MOJEM)}

Meyer and Allen (1991) propounded three models of organizational commitment for teachers' commitment to an organization. These three models of commitment have been used for measuring teachers' commitment towards an organization. The models include affective commitment, continuance commitment and normative commitment. Hoang (2012) agreed that the three model of teacher commitment is the one that influence teacher decision to remain a member of an organization.

According to Meyer and Allen (1991), affective commitment is the employee's emotional attachment to associate with, and an involvement in the organization. Employees, who are committed to the organization or emotional attached to the organization, believe in the values and goals of the organization, work for the success and stay permanently with the organization. Continuance commitment mean that the employees' awareness of perceived cost of leaving the organization. Contribution of employees to organization is one thing that determines either to stay or leave. This could be performance bonus, sick leave, friend relationship and car loan. Before employee could thought of leaving he/she would think twice. Normative commitment is the obligation to remain permanently with the organization i.e. psychological contract between employees and the organization.

Based on these findings, teachers in schools should devote more time to teaching. It is through the commitment they display that can guarantee quality education which in turn improves students' academic performance. The parents have apportioned blame to teachers as a result of students' poor performance. In order to shift this blame, it is necessary for teachers to show a serious sign of commitment to their teaching profession.

Lastly, classroom management was identified as fourth dimension of teacher quality. This result is congruent with Adeyemo (2012) which stressed that classroom management is the heart of teaching and learning. Teacher without classroom management will not produce quality teaching to students. That is why teachers must pay adequate attention to the tone of classroom situation. Venkat (2010), Osakwe (2014), and Jones et al. (2004) reported that effective teacher should acquire classroom management skills to improve the conduct of students in the classroom. The skills that teachers must have are: 1 ) use inceptive to encourage students and counselling the nuisance one, 2) create love, affection, listen to their ideas and suggestion, 3) treat them equally without favours, 4) arrange sitting space that allow free movement of people, and 5) use relevant instruction material that will bring good teaching and learning.

The findings are also supported by Chamundeswari (2013) which stated that classroom management skills involve many things such as manage time, control students' behaviour, managing sitting arrangement, control the both introverts and extroverts. Good classroom management is the beginning of teachers' effectiveness so as to bring quality teaching. Teachers must understand that it is their responsibility to make the classroom free from any forms of disturbance. They must bear it in mind that a successful classroom will be reflected in the performance of students which then will transfer glory and reward to that teacher.

Without an iota of doubt, teachers have been considered as fundamental tool that can make teaching and learning to be successful. Because of this, teacher in the classroom must be able to orchestrate the way teaching should be use to accomplish the objectives of education (Ameen, 2012). Teachers must also be able to be a part of on-going professional development to acquire more knowledge and skills that will be useful in the classroom (Osakwe, 2014). New knowledge and skills acquired will inform the teachers on how manage their classroom more effectively.

Finally, the study has successfully tested the relationship among the dimensions of teacher quality as a determinant factor that lead to students' academic performance. Based on the discussion above, it is discovered that students' academic performance cannot takes place without the input of quality teacher. One of the cardinal factors that lead to quality education is the recruitment of quality teacher. If teachers in schools are be able to incorporate the sets of dimensions, students' performance, aims and objectives will then be attainable. 


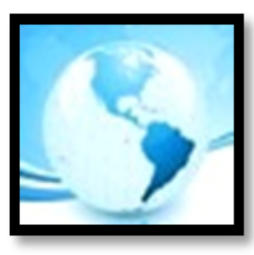

\section{IMPLICATIONS OF THE STUDY}

\section{Theoretical Implication}

Numerous theoretical contributions have emanated from this study. First, the development of sub-dimensions of TQ models paved way for this research to have comprehensive theoretical framework. The model of Teacher Knowledge Skills (Shulman, 1986); Communication Skills model (Mortimer \& Scott, 2003), the model of Teacher Commitment Skills (Meyer \& Allen, 1991) and the model of Classroom Management (Wolfgang \& Glickman, 1980). These models tested empirically and theoretically based on local educational context to have deep in-depth of quality of teachers. The synthesized underpinned theory of these models was not only contributed to the body of knowledge on teacher quality but it has created indelible framework to further explore the relationship between the categories of teacher quality and the level to improve students' academic performance.

Second, in line with the above foundation, the study contributes to the field of teacher quality skills that contribute to the improvement of students' academic performance in secondary schools. The teacher quality skills have contributed significantly to the level of enhancing teacher performance on students. Goe (2007) provided a ground model in which teachers in schools must possess certain skills in order to perform their teaching job. This finding also contributes to the understanding that teacher can developing skills that will make them remain on the job. The principal of a school has a role to play by making the teachers have institutionalized and internalized quality development practices that will made them genuine teachers.

Third, many studies have been done on teacher quality to improve students' academic performance. Likewise, no research was done on how to explore these sets of dimensions to enrich the quality of teachers in secondary schools to increase performance of students. Indeed, through this, the researcher started to fill the theoretical gaps in the literature.

Fourth, quality education depends on the availability of the quality teacher which in turn brings improvement in students' academic performance. This is one of the reasons why the students' academic performance was difficult to improve. Besides, adequate attention must be given to teacher quality in educational setting. Efforts must be double by school principal to stress teacher knowledge, communication skills, teacher commitment and classroom management so that performance of students can improve.

\section{Practical Implication}

As mentioned before, teacher quality is the heart of academic success in school. Teachers play a vital role in the development of students by inculcates values and norms that will transform society. It is confirmed that when teachers acquire these dimensions of teacher quality (TK, TC, CS and CL) for teaching and learning, performance of the students will be improving in the classroom.

Firstly, the findings contributed to the existing body of knowledge for teachers in developing requisite skills to perform well in the job, partaking in professional activities and utilize them to improve teaching in the classroom. As mentioned above, the skills possessed by teachers are the weapons they need to uplift the standard of educational system as well as the learners. When the skills are hindered or not possessed by the teachers, students will be suffering as well. This means that teachers must use every available opportunity to have these skills that are needed in classroom teaching.

Secondly, practically, this study contributes to the field of teacher development which in form of bringing innovation to the context of education which serves as a significant predictor to prepare teachers for agent of transformation. By having quality teacher in education, it is a reliable mechanism that the context of education in nearest future will be quality oriented. 


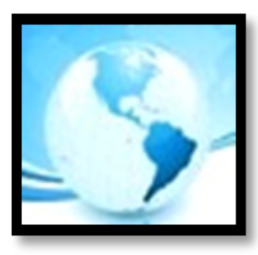

\section{MALAYSIAN ONLINE JOURNAL OF EDUCATIONAL MANAGEMENT (MOJEM)}

The students' success relies on the quality of teachers, quality of instructional materials as well as quality of policy provided for education. This is directly sending a signal to the policy makers to initiate a quality plan that will be effective to the success of education.

Thirdly, the educators should take proactive action to establish a continuous teaching skills development for teachers at all level. Most importantly, teacher should be included in the area of decision making process when policy makers are formulating policy for education so that the problem faced by the students will be discussed. It is the teachers that are in the field that are able to impart the knowledge on to the students.

Fourthly, the study also contributes that teachers have a great impact on the students' development. Therefore, education leadership should theoretically and empirically expose teachers to teacher quality dimensions (teacher knowledge, communication skills, teacher commitment and classroom management). By exposing them to these four mentioned dimensions as multidimensional learning strategies rather a single mechanism of learning at secondary school level, it will yield a more positive impact on students to be more confident in any examinations.

\section{LIMITATIONS AND DIRECTIONS FOR FUTURE RESEARCH}

This study has highlighted a useful limitation and feasible explanations are presented for directions for possible future researches. First, teachers have the potential to possess new skills to utilize in the system. In order to determine the qualities possessed by the teachers, more developmental skills acquisitions are needed for them. However, the dimensions of teacher quality that had been practiced in the system were derived from a theory based oriented. In order to enrich the validity of the findings, it would be of importance to investigate the teacher quality deeply in a more comparative ways and thus remove forms of lapses that might be committed.

Second, the combinations of qualitative and quantitative research methodologies which popularly called multiple or mix methods are strongly suggested for innovative research. Since multiple methods will assist in having better explanations of the teacher quality and students' academic performance. Using qualitative and quantitative on these variables will enrich new research findings with unique information about new qualities of teachers. This study suggests innovative research to further include teacher qualifications and teacher characteristics in teacher quality skills process since they are part of qualities the teachers must possess.

Third, there were two variables for this study, teacher quality and students' academic performance using sophisticated scientific methods (Structural Equation Modeling). Hence, the study suggests further research to investigate the correlation between the teacher quality and students' academic performance. Supplementary research should examine the nature of relationship between the mentioned variables. Additional research should investigate the correlation coefficient between the variables and applying advanced research tools like Rasch Model Analysis and others.

Fourth, the teacher quality (TQ) model was prepared solely for the relationships between TQ and SAP for the purpose of holistic understanding as well as the ability to interpret the results. Additional research is suggested to include principal, head of department and policy makers in educational sector so that the phenomenon can be understandable. Further research should also incorporate qualitative methods to gain more insight instead of quantitative used in this study. 


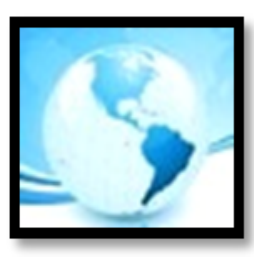

\section{CONCLUSION}

Teacher quality plays a colossal role in the improvement of students' academic performance. Teachers have been known as the guidance of the students and guide them to the right way so as to be useful to the society. Hence, the four dimensions of teacher quality are needed by teachers in order to develop and possess to improve students' academic performance in the classroom, which in turn lead to actualization of educational objectives. In fact, teacher quality is fundamental as part of skills that the teachers need in education to teach students and to cultivate further competencies.

The school is a learning place where students acquired knowledge, skills and value needed in the society. Teachers must use all the skills they possess to bring changes among these students. Also, teachers have been regarded as an agent of change in the life of students. As a result of that, teachers must go to any length to possess requisite skills in bringing these changes to school system. Schools must provide all skilful acquisition schemes to uplift the performance of teachers to improve students' abilities.

Developing an empirically tested model and importance instrument for TQ would add to the knowledge and understanding about students' academic performance in the schools' system. The model would also provide a boost at teacher quality development than conventional skills that could not bring effective changes to students. As TQ been an inevitable tool to the success of teachers in discharging their overall performance, it is quite paramount to keep abreast of latest information and skills that would make them relevant in the production of quality students. As a matter of fact, professional development can assist teachers competently and skilfully to be relevant in the teaching profession. Nonetheless, teachers would still be regarded and determinant factor of educational system and no educational system can rise above its quality teachers.

\section{REFERENCES}

Abdul Rasaq, A., Norhasni, Z. A., Zalizan, M. J., \& Anisa, S. (2010). Teachers' Perspectives towards schools' diversity in Malaysia. International Journal of Business and Social Science, 2(4), 178-189.

Adedoyin, O. O. (2011). The Impact of Teachers' In-Depth Pedagogical Mathematical Content Knowledge on Academic Performance: As Perceived by Botswana Junior Secondary School Pupils. European Journal of Educational Studies, 3(2), 277-292.

Adeyemo, S. A. (2012). The Relationship between Effective Classroom Management and students' academic Achievement. European Journal of Educational Studies, 4(3), 367-381.

Ahn, S., \& Choi, J. (2004). Teachers' Subject Matter Knowledge as a Teacher Qualification: A Synthesis of the Quantitative Literature on Students' Mathematics Achievement. Retrieved from http:// https://eric.ed.gov/?id=ED490006

Aluede, O. (2009). The teacher matters: Strategies for making the teaching profession more relevant in Nigerian educational system. International Journal of Education Science, 1(1), 39-44.

Ameen, S. M. (2012). Teacher Supply, Capacity Building Strategies and students' academic performance in Kwara State Junior Secondary Schools. (Unpublished Masters' Thesis). University of Ilorin, Ilorin. 


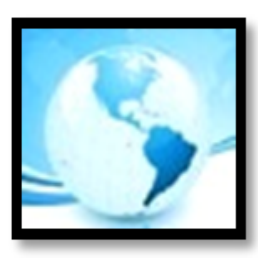

Arinde, M. R. (2010). Educational Services, Teacher Quality and Students' academic Performance in Public Senior Secondary Schools, North Central Zone, Nigeria (Unpublished Doctoral Dissertation). University of Ilorin, llorin.

Aurier, P., \& Séré de Lanauze, G. (2012). Impacts of perceived brand relationship orientation on attitudinal loyalty: An application to strong brands in the packaged goods sector. European Journal of Marketing, 46(11/12), 1602-1627.

Ball, D. L., \& McDiarmid, G. W. (1989). The Subject Matter Preparation of Teachers. Journal of National centre for research on teacher education, 89(4), 5-35.

Bell, L. (2002). Strategic planning and school management: full of sound and fury, signifying nothing? Journal of Educational Administration, 40(5), 407-424.

Byrne, B. M. (2013). Structural equation modelling with AMOS: Basic concepts, applications, and programming. NJ: Lawrence Erlbaum Associates.

Carr, W. (2006). Education without theory. British Journal of Educational Studies, 54(2), 136-159.Retrieved from : https://doi.org/10.1111/j.1467-8527.2006.00344.x

Cavalluzzo, L. C. (2004). Is National Board Certification an effective signal of teacher quality? CNA Corporation. Retrieved from http://www.cna.org

Chamundeswari, S. (2013). Teacher management styles and their influence on performance and leadership development among students at the secondary level. International journal of academic development in progressive education and development, 2(1), 367-418.

Cohen, J. (1988). Statistical power analysis for the behavioral sciences. NJ: Lawrence Earlbaum.

Choi, P. L., \& Tang, S. Y. F. (2009). Teacher commitment trends: Cases of Hong Kong teachers from 1997 to 2007. Teaching and Teacher Education, 25 (5), 767-777. Retrieved from https://moodle.eduhk.hk/pluginfile.php/379375/mod_resource/content/1/Choi\%20\%20Tang\%20(2009).pd f

Chory, R. M., \& McCroskey, J. C. (1999). The relationship between teacher management communication style and affective learning. Communication Quarterly, 47(1), 1-11.

Daramola, S. O. (2006). Research and statistical methods in education for students and researchers in tertiary institution. Ilorin: Bamitex.

Das, K. (2014). Need of Effective Communication Skills in Teaching Science in Classroom Situation. International Journal of Educational Research and Technology, 5(3), 40-42.

Day, C., Elliot, B., \& Kington, A. (2005). Reform, standards and teacher identity: Challenges of sustaining commitment. Teaching and teacher Education, 21(5), 563-577.

Elger, D. (2007). Theory of performance. In S. W. Beyerlein, C. Holmes, \& D. K. Apple (Eds.), Faculty guidebook: A comprehensive tool for improving faculty performance. Lisle, IL: Pacific Crest. 


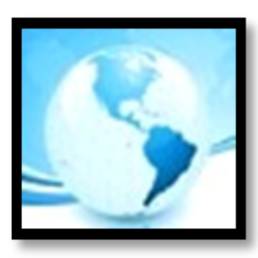

Elliott, B., \& Crosswell, L. (2001). Commitment to teaching: Australian perspectives on the interplays of the professional and the personal in teachers' lives. In International Symposium on Teacher Commitment at the European Conference on Educational Research, Lille, France.

Etuk, E. N., Afangideh, M. E., \& Uya, A. O. (2013). Students' perception of teachers' characteristics and their attitude towards mathematics in Oron education zone, Nigeria. International Education Studies, 6(2), 197204.

Fornell, C., \& Larcker, D. F. (1981). Structural equation models with unobservable variables and measurement error: Algebra and statistics. Journal of marketing research, 18(3) 382-388.

Federal Ministry of Education (2016). Nigeria Education Indicators 2016. Retrieved from https://www.nemis.gov.ng/downloads_fold/Nigeria\%20Education\%20Indicators\%202016.pdf on 20.9.2017.

Goe, L. (2007). The link between teacher quality and student outcomes: A research synthesis. Washington, DC: National Comprehensive Center for Teacher Quality.

Goddard, R. D., Hoy, W. K., \& Hoy, A. W. (2000). Collective teacher efficacy: Its meaning, measure, and impact on student achievement. American Educational Research Journal, 37(2), 479-507.

Goldhaber, D. \& Anthony, E. (2005). Can teacher quality be effectively assessed? National Board Certification as a Signal of Effective Teaching (Working Paper). Seattle, WA: Center on Reinventing Public Education.

Hair, J. F., Black, W. C., Babin, B. J., \& Anderson, R. E. (2010). Multivariate data analysis: A global perspective. NJ: Pearson.

Hacıcaferoğlu, S. (2014). Survey on the Communication Skills that the College Students of School of Physical Education and Sports Perceived from the Teaching Staff. International Journal of Science Culture and Sport (IntJSCS), 2(1), 54-67

Hanushek, E. A., \& Rivkin, S. G. (2006). “Teacher Quality.” In Hanushek, E. \& Welch, F. (2006). (Eds.). Handbook of the Economics of Education. Elsevier: Netherlands.

Harris, D. N. \& Sass, T. R. (2007). Teacher training, teacher quality and student achievement. Journal of Public Economics, 95(7), 798-812.

Holmes-Smith, P. (2001). Introduction to Structural Equation Modelling Using LISREL: ACSPRI Winter Program, School Research, Evaluation and Measurement Services. Retrieved from: http://www.scirp.org/(S(vtj3fa45qm1ean45vvffcz55))/reference/ReferencesPapers.aspx?ReferencelD=1810 926

Hoang, T. G. (2012). Reconceptualizing Organizational Commitment Using the Theory of Reasoned Action: Testing Antecedents of Multiple Organizational Behaviors. International Journal of Selection and Assessment. 20(2), 209-219.

Ige, A. M. (2017). Perceived potential of motivation strategies operating in schools to impact teacher effectiveness, by teachers in public secondary schools in Ondo State, Nigeria. Educational Studies, https://doi.org/10.1080/03055698.2017.1382326. 
Ihmeideh, F. M., Al-Omari, A. A., \& Al-Dababneh, K. A. (2010). Attitudes toward Communication Skills among Students'-Teachers' in Jordanian Public Universities. Australian Journal of Teacher Education, 35(4), 1-11.

James, K.K. (2013). Relationship between performance appraisal and teacher commitment in Kenya: Case study of public schools in Nakuru (Unpublished Masters' dissertation). Kenyatta University.

Jones, E., Watson, B., Gardner, J., \& Gallois, C. (2004). Organizational communication: Challenges for the new century. Journal of Communication, 54(4), 722-750.

Joffress, C., \& Haughey, M. (2001), “Elementary teachers' commitment declines:" Antecedents, Processes, and Outcomes. Qualitative report, 6(1), 1-22.

Lin, R., Xie, J., Jeng, Y. C., \& Huang, S. (2010). The relationship between teacher quality and teaching effectiveness perceived by students from industrial vocational high schools. Asian Journal of Arts and Sciences, 1(2), 167187.

Loy, J. (2006). Effective teacher communication skills and teacher quality. (Unpublished Doctoral Dissertation). Ohio State University, Ohio.

Luskova, M., \& Hudakova, M. (2013). Approaches to Teachers' Performance Assessment for Enhancing Quality of Education at Universities. Procedia-Social and Behavioral Sciences, 106(4), 476-484.

Kim, C., Kim, M. K., Lee, C., Spector, J. M., \& DeMeester, K. (2013). Teacher beliefs and technology integration. Teaching and Teacher Education, 29(1), 76-85.

Kline, R. B. (2005). Principles and practice of structural equation modelling (2 ${ }^{\text {nd }}$ ed.) New York: Guilford Press.

Mart, C. T. (2013). Commitment to school and students. International Journal of Academic Research in Business and Social Sciences, 2(1), 437- 442.

Meyer, J. P., \& Allen, N. J. (1991). A three-component conceptualization of organizational commitment. Human Resource Management Review, 1(1), 61-89.

Meyer, J. P. \& Maltin, E. R. (2010). Employee commitment and well-being: A critical review, theoretical framework and research agenda. Journal of Vocational Behaviour, 77, 323-337.

Moll, L. C., Cathy, A., Neff, D., \& Gonzale, N. (1992). Funds of Knowledge for Teaching: Using a Qualitative Approach to Connect Homes and Classrooms. Theory into Practice, 31(2), 132-141. doi: 10.1080/00405849209543534.

Moreno, C. (2009). Effective teachers-professional and personal skills. ENSAYOS, Revista de la Facultad de Educacion de Albacete, 24.

Morgan, M., Ludlow, L., Kitching, K., O'Leary, M., \& Clarke, A. (2010). What makes teachers tick? Sustaining events in new teachers' lives. British educational research journal, 36(2), 191-208.

Mortimer, E., \& Scott, P. (2003). Meaning making in secondary science classrooms. Maidenhead: Open University Press. 


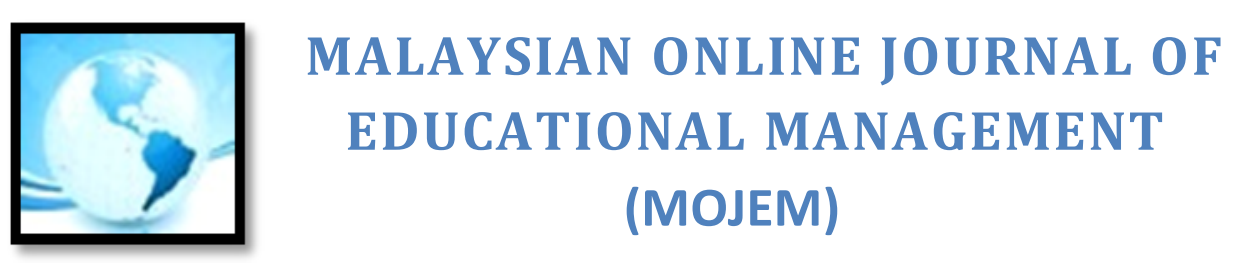

National Council of Teachers of Mathematics [NCTM]. (2000). Principles and standards for school mathematics. Reston, VA.

Niess, M. L. (2011). Investigating TPACK: Knowledge growth in teaching with technology. Journal of educational computing research, 44(3), 299-317.

Olujuwon, T. (2002). Education in Nigeria: A futuristic perspective. In A. Goody \& D. Ingram (Eds.), Spheres of Influence: Ventures and Vision in Educational Development (pp. 1-8). Australia: University of Western Australia.

Ololube, N. P. (2005). School effectiveness and quality improvement: Quality teaching in Nigerian secondary schools. The African Symposium, 5(4), 17-31.

Osakwe, R. N. (2014). Classroom management: A tool for achieving quality secondary school education in Nigeria. International Journal of Education, 6(2), 58-68.

Palos, R., \& Petrovici, M. C. (2014). Perceived Importance of Communication Skills and their Predictive Value for Academic Performance. Review of Research and Social Intervention, 46(1), 85-98.

Prozesky, R. D. (2000). Communication and effective teaching. Journal of Community Eye Health, 2(1) 234-250.

Pallant, J. (2007). SPSS survival manual: A step-by-step guide to data analysis using SPSS version 15. Nova lorque: McGraw Hill.

Rice, J. K. (2003). Teacher quality: Understanding the effectiveness of teacher attributes. Washington, DC: Economic Policy Institute.

Rubin, A., \& Babbie, E. R. (2009). Essential research methods for social work: Brooks. Cole Pub Co.

Rubio, C. M. (2009). Effective Teachers, Professional and Personal. ENSAYOS. Albacete's Faculty of Education, 24, 35-46. Retrieved from: http:// dialnet.unirioja.es/descarga/articulo/3282843

Sekaran, U., \& Bougie, R. (2010). Research Methodology for Business. 5th Ed. John Wiley \& Sons.

Shulman, L. S. (1986). Paradigms and research programs in the study of teaching: A contemporary perspective. In M. Wittrock (Ed.), Handbook of Research on Teaching (pp. 3-36). New York: Macmillan.

Smith, L. B. (2009). From fragments to geometric shape changes in visual object recognition between 18 and 24 months. Current Directions in Psychological Science, 18(5), 290-294.

Solomon, C. B. (2007). The Relationships among Middle Level Leadership, Teacher Commitment, Teacher Collective Efficacy, and Student Achievement. (Unpublished Doctoral dissertation). University of Missouri-Columbia.

Sowell, H. K. (2013). Classroom management strategies: The impact on student achievement (Unpublished Doctoral dissertation). Liberty University.

Tabachnick, B. G., \& Fidell, L. S. (2006). Multivariate analysis of grouped data. In Invited workshop presented to the meeting of the Western Psychological Association, Palm Springs, CA. 
Vaus, D. D. (2002). Surveys in social research. New South Wales: Allen and Unwin.

Vasudevan, H. (2013). The influence of teachers' creativity, attitude and commitment on students' proficiency of the English language. IOSR Journal of Research \& Method in Education, 1(2), 12-19.

Venkat, L. H. (2010). Classroom management in integrated school setup. International Journal of Education Science, 2(2), 95-102.

Vygotsky, L. S. (1962). Thought and language. Cambridge, Massachusetts Institute of Technology: M.I.T. Press

Wang, H. H., \& Fwu, B. J. (2007). In pursuit of teacher quality in diversity: A Study of the selection mechanisms of new secondary teacher education programmes in Taiwan. International Journal of Educational Development, 27(2), 166-181.

Wenglinsky, H. (2001). Teacher classroom practices and student performance: How schools can make a difference. ETS Research Report Series, 20(2), 1-37.

Wolfgang, C. H., \& Glickman, C. G. (1980). Solving Discipline Problems: Strategies for classroom teachers. USA: Ally \& Bacon.

Wu, P. (2013). Examining Pedagogical Content Knowledge (PCK) for Business English Teaching: Concept and Model. Empirical Research in Vocational Education and Training. 8(5), 1- 18. Retrieved from: https://link.springer.com/content/pdf/10.1186\%2Fs40461-016-0031-2.pdf

Yaro Ibrahim, Arshad, R. \& Salleh, D. (2017). Stakeholder perceptions of secondary education quality in Sokoto State, Nigeria. Quality Assurance in Education, 25(2), 248-267. 